\title{
Counter-terrorism Laws: How They Affect Media Freedom and News Reporting
}

\section{Lawrence McNamara}

School of Law, University of Reading, UK

Keywords: $\quad$ counter-terrorism, freedom of speech, journalism, media law

\begin{abstract}
This article examines the actual and potential effects that Australian counter-terrorism laws have on public discussion and access to information, exploring how democratic commitments to media freedom might best be balanced against contemporary demands of national security. It analyses how the laws affect the media's ability to investigate and report on matters of public interest. It explains how the research has been conducted; identifies some of the main elements of the legal framework and the way that those elements may affect, and sometimes have affected, the media; and offers some tentative conclusions about the ways that the media have been affected which are not directly, causally attributable to the suite of counter-terrorism laws but which are important to understanding the contemporary relationship between media freedom and public discussion of matters of public interest where national security is concerned.
\end{abstract}

The tension between press freedom and the tendencies by governments to restrict the scope of that freedom is perhaps the archetypal conflict between citizens and the state in liberal democracies (Keane, 1991; Schauer 1982). The legal regulation of this tension endures and fluctuates in Australia, as it does in the UK and elsewhere, but there is a clear legal recognition that the media has a legitimate and valuable role in the body politic, enhancing openness and democratic political processes (e.g. Chesterman, 2000; Meagher, 2004a). However, since 2001, most governments have introduced counter-terrorism laws that limit media freedom. These laws are the subject of this article. The focus is on the experience in Australia.

Counter-terrorism laws affecting speech have been subjected to extensive analysis in some respects. Certainly, the way individual rights and liberties are affected has received considerable scrutiny (Australian Law Reform Commission, 2006; Barendt, 2005b; Barker, 2005; Conte, 2003; Donohue, 2005-06; Head, 2002; Hocking, 2003; Hoffman, 2004; Joseph, 2004; Meagher, 2004b; Tham, 2004). However, the institutional effects of the laws have received far less attention. Media

Westminster Papers in Communication and Culture (C) 2009 (University of Westminster, London), Vol. 6(1): 27-44. ISSN 1744-6708 (Print); 1744-6716 (Online) 
organizations have raised concerns about restrictive nature of the laws (Australian Broadcasting Corporation, 2005; Australia's Right to Know, 2007; Herman, 2007: 59; Media Entertainment and Arts Alliance, 2005), as have others (Moorhouse, 2006), but the impact of the legislation has only been subjected to a preliminary scholarly analysis in Australia (Nash, 2005). In the UK, similar concerns have been raised by Cram (2006) and in the USA by the Reporters Committee for Freedom of the Press (2005). It is not yet at all clear what effects the laws will have on the open and informed public debate that characterizes liberal, democratic countries such as Australia.

Against that background, this article outlines a project that aims to identify and evaluate the actual and potential effects that counter-terrorism laws have on public discussion and access to information, exploring how democratic commitments to media freedom might best be balanced against contemporary demands of national security. ${ }^{1}$ It explores limits on media freedom and their implications for the nature and quality of public debate on matters of public interest. It does so by analysing how the laws affect the media's ability to investigate and report on terrorism and security.

The article begins by setting out the conceptual and empirical frameworks for the research. Second, it identifies key elements of the new laws and the way they may, and sometimes do, affect the media. Third, it considers how the media have been affected in ways that are not directly, causally attributable to the suite of counterterrorism laws but which are important to understanding the contemporary relationship between media freedom and public discussion of matters of public interest where national security is concerned. A brief conclusion draws together the implications of the combined direct and indirect effects.

\section{Law, Media Freedom and the Challenge of Ascertaining Effects}

Media freedom is founded upon principles of free speech. As well as being inherently valuable, free speech is instrumental in maintaining the health and vibrancy of a democracy. Free speech, it is said, is important because it enables communities to speak and listen and, as such, is central to the making optimal moral and political choices about the way we should live (Barendt, 2005a). However, this does not mean claims for the legitimacy of free speech are or should be a legal, political or rhetorical trump card. Free speech is not an unlimited licence. Established critiques of liberal theory suggest that the state has a legitimate role in restricting or regulating speech to ensure that individuals are treated with regard and respect, and that non-state actors do not corrupt public discourse. The perennial questions, of course, are at what point speech can be restricted, on what basis, and who decides (Fiss, 1987; Keane, 1991; Schauer, 1982). These issues and rationales are familiar ground for practitioners of law, media and politics who deal 
with contentious matters of public interest. Invocations of 'the public's right to know' and the conceptualization of the media as 'the fourth estate' of government are second nature to journalists, lawyers and policy makers in the field (Schultz, 1998).

There is a problem, however, when moving from theoretical analyses of free speech, or even from the potential effects of specific laws, towards ascertaining whether and how any given laws have actually affected the media. In particular, it is often difficult to tell whether restrictive laws have had effects because this may involve establishing what has not been said, which is a harder task than establishing what has been said. Nonetheless, questions about how the law affects media freedom are vitally important both for media actions and law reform. To this end, the research responds to the call by Ramraj, Hor and Roach (2005: 7) to pay attention to 'empirical questions concerning the effectiveness of anti-terrorism policy'. However, just as established critiques of free speech show that the citizenstate divide is not straightforward, any attempts to balance rights and security must move carefully if the conceptual and practical weaknesses of a simplistic opposition are to be avoided in terrorism matters (Roach, 2006).

To meet these challenges, a series of semi-structured interviews was conducted in mid-2007. The aim of the interviews was to establish what is happening on the ground when the media are reporting on national security issues. Participants were identified through the review of the literature, a review of the news media, and through formal and informal interviews and conversations with journalists, lawyers and academics in the field. Nineteen interviews were conducted. Ten interviewees were working journalists. The remaining nine were lawyers working for media organizations (in-house or in firms), or lawyers who had been involved in criminal proceedings relating to national security and terrorism. The period during which the interviews were conducted was arguably important because it was around that time that Dr Mohamed Haneef was arrested and charged with terrorism offences in circumstances where access to and the release of information was highly contentious.

Haneef was arrested in a city south of Brisbane, Australia, where he was held for 12 days before being charged with 'recklessly supporting a terrorist organization' in relation to a SIM card he was alleged to have given to a person involved with the incidents at Glasgow International Airport on 30 June 2007. The charge did not require that he knew or intended to supported an organization, but only that he was 'reckless' as to that fact. The charges against him were withdrawn when it became apparent that there was no evidence to support them, though the immigration minister cancelled his visa nonetheless. The Haneef matter is one of the most significant and controversial series of events in the law and politics of counter-terrorism in Australia and, as such, many interviewees had given a deal of 
thought to the issues that were discussed in the interviews. Following the election of a new government in late 2007, the Haneef matter became the subject of a formal inquiry (Clarke Inquiry, 2008).

The research focused on major media outlets rather than smaller and communitybased organizations. This was partly due to resource limitations, but it was also because, in a framework where the opposition is essentially between state and private power, major media organizations are in the best position to navigate the difficult issues and limitations involved. The research thus examines how the laws affect the strongest actors. That said, there would be good reason to explore the position of smaller and community-based organizations because they may feel different effects, especially where there is a sense that their communities are being targeted by particular laws or other parts of the wider community, including perhaps by the major media.

The interviewees were not and were not intended to be journalists or columnists whose primary role in their organizations is that of comment on and analysis of the legal and political issues surrounding national security. In the same vein, interviewees did not include the senior executives of media organizations. The reason for these choices was that the aim was to get a picture of what is happening when the media want to report on or investigate national security and terrorism: hence, the subjects of the interviews were the journalists who are doing that reporting, the media lawyers who are giving them advice and making judgements about what can or cannot be published, and the lawyers representing the parties in trials where there may be attempts to regulate the manner and extent to which the media can access and report information that comes before the courts.

While the project and the discussion in this article are centred on issues relating to the Australian laws and the media experience in Australia, there are at least three ways in which the analysis is more generally significant. First, the practical effect of counter-terrorism laws in Australia is that they have an impact on Arab communities, and also on Muslim communities (in Australia, the two are often conflated). In this way, the laws are very directly related to the reporting of news from, about and to those communities. In part, the globalized nature of media organizations and news reporting also gives these laws an international dimension, as does the way that foreign correspondents are very important in news reporting relating to security and terrorism. These concerns were among those at issue at the Arab Media Centre's 'Testing Journalism's Boundaries' conference in 2008 at the University of Westminster where this article was first delivered as a conference paper. Second, the implications and issues that arise with regard to politics, law and law enforcement in Australia might in future be usefully compared to similar positions overseas. Third - and the presentations at the conference led me to the view that this is more important than I had thought was the case prior to that 
conference - an investigation of how Australian counter-terrorism laws affect the media is important because it provides the occasion for a critical study of how (both putative and real) liberal democratic commitments to press freedom are operationalized in the context of national security. This seems important when, as many speakers at the conference indicated, the push for democratization and stronger press freedoms in Arab countries is of vital importance in reporting Arab news. In identifying these factors as significant, comparisons need to be made cautiously, especially as journalists in Arab countries work in phenomenally different security environments and in political contexts where press freedom does not rest on strong political, historical or legal foundations.

\section{The Legal Framework and its Immediate Effects}

When media organizations report on national security and terrorism, an extensive range of laws comes into play. Much public debate has focused on the newer legislative measures specifically directed at terrorism, but traditional forms of regulation remain extremely important. The more familiar instruments include defamation (especially in investigative reporting where a matter has not come to the courts) and contempt laws (which limit the manner and extent of reporting on matters from the time a person has been charged until the conclusion of a trial).

The suite of new counter-terrorism laws adds to the traditional regulatory framework. Of the many new or amended laws, three in particular potentially have (or it has been suggested by media groups that they might have) very significant effects on media organizations. These are the powers of the police to issue a notice to produce documents; the powers of the Australian Secret Intelligence Organisation (ASIO) to detain and question people; and powers of the judiciary to limit access to evidence and hearings. ${ }^{2}$

\section{Notices to Produce Documents}

The Australian Federal Police (AFP) have the power to demand that a person produce documents. The Anti-Terrorism Act 2005 amended the Crimes Act 1914 so that when the AFP believes it has reasonable grounds, it can issue a notice to a person to produce documents that are relevant to and will assist the investigation of 'a serious terrorism offence'. Documents must relate to matters of either finance, the disposal or acquisition of assets, travel, utilities, telephone calls and accounts, or residence. The notice may include terms preventing the person disclosing the nature or existence of the notice. Failure to produce the documents may attract a fine of up to $\$ 3300$, but breaching disclosure conditions - for example, by publishing the fact one has been issued with a notice - is a more serious offence carrying a penalty of up to two years' imprisonment. This provision affects the ability of journalists to keep their sources confidential. That, in turn, potentially limits access to information because sources cannot be assured 
of confidentiality. There was no evidence in the interviews that this had in fact happened to journalists, though certainly there was an acceptance that notes may be subpoenaed and that is a standard risk that journalists face.

\section{Questioning and Detention Powers}

The powers of ASIO, Australia's domestic intelligence agency, have been expanded so that ASIO may seek warrants to enable its agents to question a person for the purposes of investigation, or to detain a person for such questioning. A warrant may be sought where the minister (and then a judge) is satisfied that 'there are reasonable grounds for believing that issuing the warrant ... will substantially assist the collection of intelligence that is important in relation to a terrorism offence' and 'that relying on other methods of collecting that intelligence would be ineffective'.

Where a warrant is issued then a person must give information, or produce records or things, that is/are or may be relevant to intelligence that is important in relation to a terrorism offence'. A refusal to answer questions may attract a penalty of five years imprisonment. Where secrecy conditions attach to the warrant then disclosing its existence is punishable by two years imprisonment. Further, in the two years after the warrant expires it will be an offence to disclose any 'operational information' that is known by virtue of the issue of the warrant or questioning under it. This offence is punishable by five years' imprisonment. Here, 'operational information' is defined as including an 'operational capability, method or plan'. This means that the existence of the warrant still cannot be disclosed because, on the face of it, the use of warrants to obtain intelligence would seem to be an operational method. It would seem almost impossible to disclose any information acquired because, even though the prohibition applies only to operational information, the nature of intelligence work makes it impossible to know whether something is or is not 'operational information'.

For the media, these laws render journalists vulnerable to ASIO questioning if the agency thinks the journalist may have information that will be useful for the collection of intelligence relating to terrorism offences. The journalist need not be aware that they have information which the authorities see as significant, and the information need not be anything admissible in evidence at a criminal trial. Sources, then, cannot be sure that confidentiality will be maintained.

It might be argued that journalists can be compelled to reveal their sources under the law as it stands and that a failure to do so may render the journalist vulnerable to imprisonment on the grounds they will be in contempt of court. However, ASIO powers are very different from contempt laws. Experience suggests that contempt penalties are almost certain to be less (Senate Standing Committee, 1994). In addition, secrecy provisions accompanying ASIO warrants mean that it is 
probably impossible to gather any support from other journalists, media organizations or a member of parliament to try to resist the demands. Third, and this is the most significant difference and very important, the way in which journalists can be brought before the courts is fundamentally different under the ASIO laws than under the general law.

In the ordinary course of events, journalists will only be required to identify sources when a case is before the courts. For example, where a person is prosecuted on suspicion of having leaked information to the press, then a journalist may then be asked to reveal the source of information they obtained for a story. Adhering to their Code of Ethics, the journalist will not do so and is vulnerable to punishment for contempt. However, ASIO laws do not require the state to have compiled a case against a person who is to be prosecuted. Rather, the ASIO laws enable the security authorities to issue a questioning warrant and ask the journalist, 'Who is your source?' A journalist who stays silent or says they will not reveal their sources will have committed an offence punishable by five years' jail.

While interviewees thought it unlikely that journalists would be subjected to questioning and detention, the coercive powers under these laws have the potential to affect the way journalists, editors and media lawyers make judgements and decisions about news gathering and publication. However, even if not applied to journalists, the secrecy of the regime and the punishments for offences certainly means that it will be very difficult to access and publish information about the ways the laws are applied in the community more generally. There was considerable concern about the extent to which the authorities would pursue a breach of laws - for instance, publishing the fact that a warrant existed or publishing an answer to a question - but a great difference of opinion was evident. On one set of views, it was thought that police would pursue a breach of the law without hesitation, and this was especially thought to be the case where any secrecy provisions had been breached. The rationales, it was thought, could range from teaching the media a lesson, through to the need to pursue secrecy breaches aggressively in order to justify the authorities' standard position that secrecy is extremely important. An alternative view was expressed by other interviewees who thought there would be a great reluctance to pursue the media because it is such a powerful institution and tends to 'bite back'. However, the uncertainty of what might happen was clearly a matter of some concern.

\section{Secrecy in Court}

The third set of important laws governs court reporting. All courts can close proceedings at some times but the National Security Information (Civil and Criminal Proceedings) Act 2004 ('the NSI laws') places substantial new restrictions on media access to evidence. 
The laws derive from the government's concern that court proceedings are usually open to the public and defendants ordinarily know all the evidence against them, but sometimes this evidence may prejudice national security. In some circumstances the government would not want any information at all revealed to the public or even to the defendant. However, without evidence the charges against an accused could not be proved or the trial may be unfair to the accused ( $R$ v. Lappas and Dowling [2001]). The unpalatable alternative would be that all or some of the charges could be withdrawn. Rather than risk this, the Commonwealth enacted the NSI laws with the stated objects being 'to prevent the disclosure of information ... where the disclosure is likely to prejudice national security, except to the extent that preventing the disclosure would seriously interfere with the administration of justice'. The effect is that a trial can proceed even where the accused will not have access to all the evidence relied on by the prosecution. Evidence may be given, for example, in the form of summaries of documents, rather than the original and complete documents being tendered and being the subject of cross-examination.

The NSI procedure is complex and time-consuming. Where the prosecutor or defendant intends to rely on evidence relating to national security then they must notify the Attorney-General and the court. Then, the Attorney-General evaluates the extent to which the evidence 'is likely to prejudice national security', which is defined to mean that 'there is a real, and not merely a remote, possibility that the disclosure will prejudice national security'. The Attorney-General may then ask the court to rely on a summarized form of the evidence, or the relevant document may have information deleted from it, or may ask that a witness not be called for examination. Next, the court then hears argument about the extent to which the Attorney-General's view should prevail. The court will be closed for this argument.

Under section 31 of the Act, the court can decide to prohibit disclosure, permit some disclosure, or permit full disclosure. The court must consider:

- whether, having regard to the Attorney-General's certificate, there would be a risk of prejudice to national security [if the information was disclosed in court]; [and]

- whether any such order would have a [not insubstantial, insignificant or trivial] adverse effect on the defendant's right to receive a fair hearing, including in particular on the conduct of his or her defence; [and]

- any other matter the court considers relevant.

The court must give greatest weight to the first of these factors.

Media organizations have two significant problems in these circumstances. First, while the court may hear media submissions about how evidence should be dealt with, the media lawyers will have been totally excluded from the process up to that point. As one lawyer put it, 'we are making submissions in the dark'. Put simply, it 
is impossible to make a persuasive argument in any given set of circumstances when you do not know, even in outline form, what the circumstances are. It was suggested by another lawyer that the legal representatives of media organizations could and should be treated differently from their clients because, as lawyers, they are officers of the court. That is, even if represented or reporting journalists are not permitted to be in court, their lawyers should be permitted to be there. Second, even where submissions might be made effectively, the legislation itself does not provide for any consideration of open justice unless the court chooses to consider it under the 'any other matter' heading. With the scales deliberately weighted in favour of the national security interest, it will be difficult to persuade the court that open justice should be preferred.

The NSI legislation also provides an alternative way of dealing with security-related information, but it is potentially even more restrictive. Under section 22 the prosecutor and defendant may reach an agreement about how they will deal with evidence. It may be that they agree on a far more restrictive arrangement than the court would order were disclosure issues contested. The court must approve any proposed agreement but, not least because contested procedures are disruptive and time-consuming, the court may decide that the agreement is acceptable. It was said by one lawyer that an agreement 'means the shutters go up' and nothing is revealed to the media.

Of the statutes discussed above, the interviews suggested that only the last of these has had any clearly identifiable effects. Terrorism cases are invariably and appropriately matters of great public interest but by June 2008 the NSI Act had been invoked in proceedings involving 28 defendants (Attorney-General's Department, 2008: 5). Although suppression orders could possibly have been used to the same effect, the media would at least have been able to make informed submissions if suppression orders were proposed.

It does not appear that notices to produce have been issued against journalists during investigations. However, documents and notes have been subpoenaed in several instances relating to the prosecution of offences. The best known in Australia concerns the prosecution of Jack Thomas. After Thomas was acquitted of some terrorism charges, the $\mathrm{ABC}$ broadcast interviews they had conducted with him before the trial took place (Neighbour, 2006). These interviews became the basis on which a re-trial was successfully sought $(R v$. Thomas). The secrecy provisions associated with the provisions of the ASIO laws means that while there is nothing to indicate that any of those laws have been relied upon with respect to the media, one cannot be certain. Several journalists commented that they were certainly not aware of any use of the laws, but this was immediately followed with a comment to the effect of, 'But we don't know!' It may also be that the ability to intercept phone calls may mean that investigating agencies do not need to rely on 
more up-front procedures. The sense of most journalists and lawyers was that journalists' phones are not being monitored directly, but they are vulnerable to being monitored when they make or receive calls to people whose conversations are being intercepted.

\section{Indirect and Contextual Effects}

Although counter-terrorism laws appear to have had only limited direct effects on the media, does it necessarily follow that the laws are having no other significant effects on media freedom? The interviews suggest that the media have many concerns about their freedom and that anti-terrorism laws are relevant to those concerns, even if not in a direct or causal way.

\section{Understanding the Laws}

One of the most disarmingly frank comments made was by a journalist who, in response to a question of what they thought that journalists could do better in dealing with the laws was: 'Well, we could do a better job of understanding them.' It was a simple statement of the difficulties that face journalists in dealing with the laws: they are very, very difficult to understand for anyone not versed in reading legislation. And, as a lawyer put it to me, even for those who are, the laws are still a somewhat complex maze. There are very few lawyers working with the laws on a regular basis, and especially not media lawyers. A lawyer who had provided advice on publication regarding a terrorism matter said that they 'could recite the law of defamation for you from beginning to end right here and now, but I'd have to have a careful look at the stuff to be able to do any more than talk in general terms'. The implications of this complexity cannot be understated.

First, it may be difficult to ascertain under just what laws a person has been detained by police. The freedom to report that a person has been detained will vary according to the laws that have been used to detain the person. Second, even once the journalists know what laws are at work, there is the next question of what can or cannot be published. For example, in the Haneef matter there was a reluctance to report the name of the magistrate hearing the initial applications to extend the time for questioning. However, there was no suppression order or anything like it that prevented the name from being published. Third, there were journalists who found that the legal advice they were receiving was not immediately helpful because, for instance, the lawyers were uncertain about examining case-related documents that had been acquired by the journalists. One had the lawyer's response relayed to them by a staff member: 'I can't look at those documents. I'm not talking to [that journalist]. I'll go jail for five years.' The documents in question were not, however, related to ASIO matters. They were documents that were available from ordinary sources in the normal course of events. 
It may well be the case that many documents can actually be accessed, and much can be reported, but the experience of journalists was that few people involved in the process had a good grasp of what was and was not permissible where terrorism cases were concerned. This was exemplified by the ongoing use of incorrect terms. For example, even some weeks after the Haneef matter 'it was being referred to [by journalists and others] as "preventative detention" when it was not'.

In all, the sense of journalists, even those who are dealing regularly with national security matters, was that they themselves frequently did not have a really sound grasp of the laws. They quite simply could not get that grasp because of the complexity of the legislation and because of the willingness of the government and the police to deal with information in a way that did not help put the full story into its correct legal context and get it out into the public domain.

The most worrying implication of the complexity of the laws is that it makes it very, very difficult for journalists to ask the right questions. For example, when a minister makes a statement about the status of the investigation or detention of a person, it is almost impossible to ask the question that will compel a more complete explanation of the facts and their context. One example of this is the position of Dr Haneef while he was being questioned: it was very unclear to the large number of journalists and their lawyers exactly on what basis Haneef was being held and how the detention could proceed, but this point could only be pushed in general terms rather than questions that went directly to the legal basis of detention.

\section{Cultivation of Sources}

The interview data suggests that there is good reason to think that the range of counter-terrorism laws is having a meaningful effect on the ability of journalists to cultivate good sources.

The complexity of the laws is relevant here again. It affects journalists' access to information because it is easy for police or security agencies to suggest that the laws are such that information cannot be released, or should not be published, or that requests to deal with information in certain ways should be complied with. But, similarly, the wide scope of the laws is also important. These factors can affect the information that sources (such as families or friends of people who are under investigation) will provide to journalists. I was told on more than one occasion that the families of suspects 'go to ground' once a person is arrested. A journalist said the type of comment that police may make to a family in warning them not to talk to the media was, 'Well, you know, we've got a lot of power under the new laws.' When I discussed this with a lawyer, the lawyer's response was:

[The journalist] is right. They do have a lot of powers. [Families of suspects] are warned by their lawyers not to talk to the media because if they go and 
say to a television camera, 'My brother is a good man and I stand by him' then they run the risk of being prosecuted for supporting terrorism.

In response to the question of whether this advice is heeded and is thus the reason for the reluctance to talk to the media, one lawyer's response was, 'It varies. But they [take notice of the advice] after the first time their comments are misreported.'

At a wider level, the interviews revealed a deep concern that the relationship between Muslim communities and the media was strained in a way that was reducing the extent to which those communities trusted the media. The strongest comment was that 'the media are seen as proxies for the authorities'. Others tended to think it was more a question of marginalization and distrust of major media organizations which had not treated Muslim communities well and those communities were, in the context of a wider sense of marginalization, less willing to trust the media. The perception, it was said, is that even if people accepted that the media were not working for the police then it was still thought that some journalists 'may look at the police favourably ... or their work will be used by the authorities at the end of the day. And there has been a bit of truth in that.' Community cautiousness seems justified because it appears the authorities monitor and exploit the way that a person deals with the media. Added to this, argued one journalist, the Australian media is, on the whole, 'all a bit Anglo' and does not have the base of community contacts that provides a base for the trust in the media that is needed.

Silence has a significant effect on what the public gets to know. When someone will not speak to the media then a journalist's inquiries and analysis will take account of that. If it is not clear why a person refuses to speak then that may lead to adverse judgments: 'if you ask a question and they don't answer, you might form a different judgment about why they aren't speaking, whether they've got something to hide. It has an impact on the story.' One journalist with significant contacts in Muslim and Arab communities argued that there was a more widespread silencing of opinion, stretching from individual interviews through to general discussion and talkback radio: 'I think people were forthcoming before, they were much more vocal... I think that people have become much more paranoid now [and] they're not speaking... There's a self-censorship.' This, it was said, is a cause for concern: 'We don't know what their thoughts are because they're not talking any more.'

\section{Access to Information}

The principles of open justice dictate that information which comes before the courts should usually be available. For example, transcripts of trials or documents tendered in evidence may be accessible. In addition, there may well be a large 
amount of information which should still be accessible to the public and over the release of which there are no formal restrictions. However, the experience of journalists has been that it is very difficult to get information where terrorism cases are concerned. The reason for this, according to both lawyers and journalists interviewed, is all tied up with questions of trust and the lawyer's or court's knowledge of the journalists.

For an unfamiliar journalist to obtain information will be difficult for any number of reasons. Among them, lawyers and court staff are simply busy. Lawyers especially may not be certain about how information will be used, and may prefer that as little information about their client as possible is out in the public domain. On the other hand, where journalists are familiar with the processes of the courts and regularly in touch with the lawyers appearing in them, then they will have much better access to information. It was observed by almost every journalist and lawyer I spoke to that it was not a coincidence that the transcript of an interview in the Haneef matter was leaked to a Brisbane-based journalist, and a well-respected one at that.

In a similar vein, observations were made by numerous journalists about the importance of having people on the ground in any given place so that they can get reliable information. Once more, the Haneef case was cited as an example of this where, on the one hand, the best work was coming from the Brisbane-based Hedley Thomas of The Australian, while, on the other, most of those covering the story had very little knowledge of the Gold Coast area which was the focus of attention for a deal of the time. This theme was picked up again in relation to the need to have good international sources.

The Haneef matter (once more) was cited by several interviewees as an example of the value of international correspondents. The ABC's Raphael Epstein was able to get to the heart of information in London because he was based in London, and the Fairfax papers had someone in Bangalore 'who was able to humanize Haneef by providing pictures of the family'. In an environment where the global reach of national security issues is clearly important, the media needs to address that reach appropriately.

Both of the matters above have significant resource implications and requirements. However, if the media is to be able to provide quality reporting of events then it appears from the interview data that the best way to do so is to resource journalism, even though it may not provide big stories on an ongoing basis. The benefit is that court reporters and a diverse range of international correspondents will be able to get information that is difficult to access otherwise. Relying on reciprocal arrangements is not suitable, as one journalist put it, 'because NBC or the $\mathrm{BBC}$ or whoever it is are just not interested in the same stories or the same 
aspects of those stories that an Australian audience is'. In short, while an important aspect of media freedom and public discussion relates to issues of regulation, the investment of resources is a dimension that cannot be ignored.

\section{Patterns of Policing and Media Management}

Where terrorism matters are concerned, almost all journalists and lawyers expressed deep reservations about the patterns of policing and media management. The widespread perception was that use of the phrase 'operational information' was deliberately employed to enable both the government and the police to selectively disclose or withhold information. Among the greater concerns was that, while to some extent there was a sense that this was to be expected of ministers because of the inherently political nature of government (though it was certainly seen as unacceptable), there was a widespread sense that policing had been politicized in a way that was at once detrimental to the public's access to information and analysis, and simultaneously being developed by state police forces following the lead of their federal counterparts. Four particular examples were given in the interviews.

One related to the presence of television cameras (from one organization only) at a raid by the AFP. The other concerned the perceived strategic use of press conferences between the time a person was arrested and charged, and the time which is often just hours - the person came before a court to apply for bail. This attracted particular criticism from two lawyers who noted that the Commonwealth was supposed to be a model litigant and the use of press conferences in this way was inconsistent with that. It was also noted that press conferences that outlined a case against the accused put the defence lawyer immediately on the back foot because 'the police are not subject to ethical duties not to misrepresent information', whereas lawyers have an ethical obligation that prevents them from doing so. The third concerned the prosecuting or investigating bodies making applications for orders out of court hours - for instance, in the evening at a judge's home - because this then prevented the media attending what would in the ordinary course of events be an open hearing. The fourth concerned the treatment of leaks of confidential information from within government or police. There was a clear consensus from both lawyers and journalists that the selective (un)willingness to pursue and identify leaks was part and parcel of a wider strategy to shut down access to information.

While none of this can be sheeted home as being directly attributable to the enactment of the anti-terrorism laws, these matters were certainly seen by the journalists and lawyers as a key aspect of how the state deals with and manages information that reaches the media and the public. There was certainly no sense conveyed by the interviewees that a change of government would see things change in any significant sense. These are patterns that require much more 
investigation, especially with respect to the relationship between (at least) policing, media management and the substance of the anti-terrorism laws.

\section{Conclusions, Implications and the State of Reporting on National Security}

In ascertaining and evaluating the effects of laws, the combination of direct and indirect effects, the impossibility of knowing all the facts that one needs to know in order to judge the behaviour of security authorities (for there will be genuine reasons for secrecy in some instances), and the high levels of distrust pose major hurdles for any analysis of or judgement about the effects of the laws. Having said that, at least some conclusions can fruitfully be drawn.

In spite of the various hurdles journalists face in dealing with national security matters, their commitment to rigorous reporting seems strong. There was absolutely no evidence of reluctance to pursue stories that might place journalists in a difficult position with respect to the need to protect their sources in the face of prosecution. By the same token, there was a strong commitment to not undermining policing and investigation of matters involving terrorism. There was no expression of doubt that the security agencies have reason to be concerned about terrorism. But there were deep doubts and reservations harboured about the way that the approach tended to be one of non-disclosure and selective disclosure of information. The mistreatment of the Haneef case generally left the interviewees I spoke with of the strong opinion that the media have a vital role to play as a watchdog. One journalist said of Haneef, 'if it wasn't for the media attention ... he would have been left in [the cells] or just deported. His goose would have been cooked.'

The laws have clearly had a direct effect on court reporting. This is worrying because it is in courts that the public can legitimately expect that much information will be brought to light, and it is in courts that information is tested and scrutinised. In courts, it is difficult for government, police, other agencies of the state, or anyone else to spin or manipulate information. The NSI laws cast something of a pall over this process. They require the public to have a great deal of trust in legal institutions and processes, and in the state and its agencies. The interviews suggest that scepticism and distrust is a constant feature of the interactions involved in news gathering and reporting. These themes feed into the indirect and contextual effects of counter-terrorism laws.

Where news from and about Arab and Muslim communities is concerned, there is reason to see the levels of distrust as heightened. There is insufficient data in the interviews to draw any firm conclusion about whether this is significantly affecting the way news is gathered or reported, but - when read in light of other direct and indirect effects - there does seem to be enough to suggest that there is good 
reason to be concerned and that the effects need to be ascertained with greater precision, and actions should be considered which alleviate potential and actual negative effects.

The interviews reveal the need for a much greater degree of openness by the authorities: where something can be made public, then it should be made public. The security authorities will almost inevitably tend to err on the side of caution when it comes to openness, but there is a difference between erring on the side of caution and keeping information hidden unnecessarily. It is difficult to know whether the latter is in fact happening, but media practitioners seem fairly convinced that it is. At the very least, that perception needs to be addressed because it fosters a culture of distrust. Similarly, whether or not media organizations are aligned with authorities in their treatment of marginalized Arab and Muslim communities, the perception of such an alignment needs to be carefully and thoroughly addressed.

\section{Notes}

1 The initial stages of this research were funded by a Macquarie University Research Development Grant. I am grateful to Philippa Hofbrucker and Jonathan Light for their research assistance on the project and to all those who agreed to be interviewed. An earlier version of this article was released as a working paper (McNamara, 2007) and I am grateful for the opportunity to present at the Arab Media Centre's 'Testing Journalism's Boundaries' conference at the University of Westminster, 2008. For the major publication of the research findings see McNamara (2009).

2 The discussion here is presented for a non-legal audience and will avoid many technical but often significant aspects of the laws. It also omits references to some statutes and specific sections of legislation. For a detailed analysis, see McNamara (2009).

\section{References}

Attorney-General's Department (2008) National Security Information (Civil and Criminal Proceedings) Act 2004 Practitioners' Guide, Attorney-General's Department, Canberra.

Australian Broadcasting Corporation (ABC) (2005) Submission to the Senate Legal and Constitutional Committee, Inquiry into the Provisions of the AntiTerrorism Bill (No. 2) 2005, Submission 196 (11 November).

Australian Law Reform Commission (2006), Fighting Words: A Review of Sedition Laws in Australia: Report 104, Sydney: ALRC.

Australia's Right to Know (2007) Report of the Independent Audit into the State of Free Speech in Australia, Sydney: Australia's Right to Know.

Barendt, E. (2005a) Freedom of Speech, 2nd edn, Oxford: Oxford University Press. 
Barendt, E. (2005b) 'Threats to freedom of speech in the United Kingdom?', University of New South Wales Law Journal 28(3): 895-9.

Barker, I. (2005) 'Human rights in an age of counter-terrorism', Australian Bar Review 26: 267-86.

Chesterman, M. (2000) Freedom of Speech in Australia: A Delicate Plant, Dartmouth: Ashgate.

Clarke Inquiry (2008) Report of the Clarke Inquiry into the Case of Dr Mohamed Haneef, http://www.haneefcaseinquiry.gov.au (accessed 19 Feb. 2009).

Conte, A. (2003) 'A clash of wills: counter-terrorism and human rights', New Zealand Universities Law Review 20(3): 338-63.

Cram, I. (2006) 'Regulating the media: some neglected freedom of expression issues in the United Kingdom's counter-terrorism strategy', Terrorism and Political Violence 18: 335-55.

Donohue, L.K. (2005-6) 'Terrorist speech and the future of free expression', Cardozo Law Review 27(1): 234-341.

Fiss, O. (1987) 'Why the state?', Harvard Law Review 100: 781-94.

Head, M. (2002) "Counter-terrorism" laws: a threat to political freedom, civil liberties and constitutional rights', Melbourne University Law Review 26(3): 666-89.

Herman, J. (ed.) (2007) State of the Nenss Print Media in Australia 2007: Supplement to the 2006 Report, Sydney: Australian Press Council.

Hocking, J. (2003) 'Counter-terrorism and the criminalisation of politics: Australia's new security powers of detention, proscription and control', Australian Journal of Politics and History 49(3): 355-71.

Hoffman, P. (2004) 'Human rights and terrorism', Hunan Rights Quarterly 26(4): 932-55.

Joseph, S. (2004) 'Australian counter-terrorism legislation and the international human rights framework', University of New South Wales Law Journal 27: 42853.

Keane, J. (1991) The Media and Democracy, Cambridge: Polity Press.

McNamara, L. (2007) Australian Counter-terrorism Laws and Limits on Media Freedom, Working Paper No. 1 Reading University Law Department (24 October), available at http://papers.ssrn.com/sol3/papers.cfm?abstract_id=1024586 (accessed 19 Feb. 2009).

McNamara, L. (2009) 'Closure, caution and the question of chilling: how have Australian counter-terrorism laws affected the media?', Media \& Arts Law Review 14(1): 1-30.

Meagher, D. (2004a) 'What is political communication? The rationale of the implied freedom of political communication', Melbourne University Law Review 28(2): 438-73. 
Meagher, D. (2004b) 'Back to the future: the War on Terror and its impact on civil liberties', Public Law Review 15(3): 177-82.

Media, Entertainment and Arts Alliance (MEAA) (2005) Submission to the Senate Legal and Constitutional Committee, Inquiry into the Provisions of the Anti-Terrorism Bill (No. 2), Submission 198 (November).

Moorhouse, F. (2006) 'The writer in a time of terror', Griffith Review 14: 4-54.

Nash, C. (2005), 'Freedom of the press in the new Australian security state', University of New South Wales Law Journal 28: 900-8.

Neighbour, S. (2006) 'The convert', Four Corners, ABC Television, 27 February 2006 http://www.abc.net.au/4corners/content/2006/s1580223.htm (accessed 8 Sept 2008).

Ramraj, V, M Hor and K Roach (eds) (2005), Global Anti-Terrorism Law and Policy, Cambridge: Cambridge University Press.

Reporters Committee for Freedom of the Press (2005) Homefront Confidential, 6th edn, How the War on Terror Affects Access to Information and the Public's Right to Know, New York: RCFP.

Roach, K. (2006) 'Must we trade rights for security? The choice between smart, harsh or proportionate security strategies in Canada and Britain', Cardozo Law Review 27(5): 2151-221.

Schauer, F. (1982) Freedom of Speech: A Philosophical Inquiry, Cambridge: Cambridge University Press.

Schultz, J. (1998) Reviving the Fourth Estate: Democracy, Accountability and the Media, Cambridge: Cambridge University Press.

Senate Standing Committee on Legal and Constitutional Affairs (1994) Off the Record: Shield Laws for Journalists' Confidential Sources, Canberra: AGPS.

Tham, J. (2004) 'Casualties of the domestic "War on Terror": a review of recent counter-terrorism laws', Melbourne University Law Review 28(2): 512-31.

\section{Legislation}

Anti-Terrorism Act 2005

Crimes Act 1914

National Security Information (Civil and Criminal Proceedings) Act 2004

\section{Cases}

R v. Lappas \& Dowling [2001] ACTSC 115

$\mathrm{R} v$. Thomas (No. 4) [2008] VSCA 107 